\title{
ASSESSMENT OF ANTIBODY TITER AND LYMPHOID ORGANS WEIGHT FOLLOWING NEWCASTLE DISEASE VACCINATION AND FEED-SUPPLEMENTATION OF VITAMIN-C, PROBIOTICS AND ANTIBIOTIC-GROWTH-PROMOTERS IN JAPANESE QUAILS
}

\author{
Mirza Mienur Meher ${ }^{1}$, Nusrat Jahan², Marya Afrin ${ }^{3}$ \\ ${ }^{1}$ Department of Microbiology and Public Health, Faculty of Veterinary Medicine \\ and Animal Science, Bangabandhu Sheikh Mujibur Rahman \\ Agricultural University, Gazipur-1706, Bangladesh \\ ${ }^{2}$ Department of Physiology, Faculty of Veterinary Science, \\ Bangladesh Agricultural University, Mymensingh-2202, Bangladesh \\ ${ }^{3}$ Department of Anatomy and Histology, Faculty of Veterinary Science, \\ Bangladesh Agricultural University, Mymensingh-2202, Bangladesh
}

Received 22 October 2020; Received in revised form 25 February 2021; Accepted 26 February 2021

\begin{abstract}
Newcastle disease (ND) is a highly contagious viral disease. This study was conducted to determine the antibody titer in Japanese quails following vaccination against ND and feed-supplementation with vitamin-C, probiotics and antibioticgrowth-promoters. Forty Japanese quails were equally grouped in four groups $\left(\mathrm{A}_{1}\right.$ to $\left.\mathrm{A}_{4}\right)$ and were vaccinated by LaSota, $\mathrm{B}_{1}, \mathrm{~F}$ and VG/GA strains, respectively, at the age of 10 days. Another forty Japenese quails were equally grouped in four groups $\left(\mathrm{B}_{1}\right.$ to $\left.\mathrm{B}_{4}\right)$, were vaccinated with the vaccines of the previous groups that showed a higher effect, and were fed with mesh-feed (control- $\left.\mathrm{B}_{1}\right)$, supplemented with vitamin- $\mathrm{C}\left(\mathrm{B}_{2}\right)$, probiotics $\left(\mathrm{B}_{3}\right)$, and antibiotic growth promoter $\left(\mathrm{B}_{4}\right)$. Serum samples were obtained on 2, 4, 6, 8, 10 and 12 weeks of age and were subjected to a hemagglutination inhibition test. The mean antibody titer $\left(\log _{2}\right)$ had no significant difference between groups $\mathrm{A}_{1}-\mathrm{A}_{4}$. The highest titers were recorded in $\mathrm{A}_{4}$ $(6.20 \pm 0.37)$ and $A_{3}(6.00 \pm 0.71)$. The mean titer was significantly different among the groups at 4 weeks, but insignificant in the other weeks of the supplemented groups. A higher mean titer was found between 8 and 10 weeks in group $\mathrm{B}_{2}$ $(7.40 \pm 0.60)$ and $B_{3}(7.20 \pm 0.58)$. The relative weights $(\mathrm{gm} / \mathrm{kg})$ of the spleen, thymus and bursa were significantly higher in group $\mathrm{B}_{3}(1.947 \pm 0.109,5.951 \pm 0.312$ and $2.624 \pm 0.083$, respectively). They had no significant correlation with antibody titer at 12 weeks. In conclusion, vitamin-C and probiotic supplemented feeds can boost up the antibody titer against ND in Japanese quail when given during VG/GA strain vaccination.
\end{abstract}

Key words: antibody, NDV, vaccination, vitamin C, probiotics, Japanese quail

\section{INTRODUCTION}

Japanese quails (Coturnix coturnix japonica), belonging to the family Phasianidae, were popular as small game birds and now are commonly used

Corresponding author: Assist. Prof. Marya Afrin

E-mail address: marya.afrin@bau.edu.bd

Present address: Department of Anatomy and Histology, Faculty

of Veterinary Science, Bangladesh Agricultural University,

Mymensingh-2202, Bangladesh

Phone: +8801719360828

Copyright: (C) 2021 Meher M.M. This is an open-access article published under the terms of the Creative Commons Attribution License which permits unrestricted use, distribution, and reproduction in any medium, provided the original author and source are credited.

Competing Interests: The authors have declared that no competing interests exist.

Available Online First: 17 May 2021

Published on: 15 October 2021

https://doi.org/10.2478/macvetrev-2021-0016 for commercial production of eggs and meat (1). Though quails are more resistant to infectious diseases compared to chickens, few infectious diseases are encountered in quails. Particularly, Japanese quails have a certain degree of natural resistance to Newcastle disease virus (NDV) infection (2) but it may act as a carrier. Several records of Newcastle disease (ND) outbreak in Japanese quails have been reported $(3,4)$. The ND commonly known as Ranikhet disease is a highly contagious viral disease caused by NDV belonging to Paramyxovirus type 1 of the genus Avula virus of the family Paramyxoviridae (5). This ND virus is readily transmitted from one bird to another, whereas good biosecurity practices and/or 
vaccination program could keep it under control (6). In this regard, vaccines with different NDV strains are commonly practiced. The live lentogenic vaccine strains LaSota, B1, F and VG/GA are most commonly used in poultry. These vaccines are assessed by determining the level of antibody titer after vaccination. The antibody titer of ND vaccines is commonly measured by Hemagglutination Inhibition (HI) test which is still the most widely used serological method and is considered as the gold standard test for this disease (7). Also, different feed supplements can improve the immune response. Vitamin $\mathrm{C}$ given after vaccine improves the cell-mediated and humoral immune response in poultry $(8,9)$. It is an important antioxidant, stimulating and regulating the immune system (10). Probiotics stimulate the production of antibodies (11, 12). Lactobacillus and Bifidobacterium are the most common genera used for probiotics (13). Antibiotic growth promoters (AGP) (14) have been widely used following vaccination despite the described probiotic's advantages. Although several comparative studies were performed on antibody production in chicken after ND vaccination, there are limited studies on the effect of probiotics and AGP on HI in Japanese quail. Hence, this study was designed to determine the level of antibody titer in Japanese quail after vaccination by different ND vaccine strains. Moreover, this study was also focused on the comparative effects of vitamin C, probiotics, and AGP on HI titer as well as lymphoid organs in Japanese quail.

\section{MATERIAL AND METHODS}

\section{Experimental birds and management}

A total of eighty (80) healthy day-old Japanese quails (Coturnix coturnix japonica) were collected from a local commercial quail farm located in Mymensingh Sadar of Bangladesh. The birds were accommodated in experimental cages, being exposed to 16 hours of continuous natural and artificial light. Fresh drinking water and mash feed formulated according to Razee et al. (15), were offered ad-libitum to the birds. Adequate hygiene and sanitation were maintained throughout the experiment.

\section{Experimental design}

In this study, the whole experiment was divided into two phases. The first phase of the experiment was designed to determine the efficacy of different ND vaccine strains. According to this, 40 birds were assigned and equally allocated ( $\mathrm{n}=10$ /group) into four groups named $A_{1}, A_{2}, A_{3}$ and $A_{4}$. At the age of 10 days, they were vaccinated with ND vaccine of "LaSota", "B1", "F" and "VG/GA" strain, respectively. The vaccines were administered through the intraocular (IO) route. The second dose was administered at the age of 30 days according to the manufacturer's recommendation. The birds were fed with the mash feed formulation. For the second phase of the experiment, 40 Japanese quails (one-day-old) were equally divided ( $\mathrm{n}=10 /$ group) into four groups $\mathrm{B}_{1}, \mathrm{~B}_{2}, \mathrm{~B}_{3}$ and $\mathrm{B}_{4}$. The birds from the first phase of the experiment showing a high immune response and high level of serum antibodies were vaccinated with the NDV strain. The vaccination schedule was the same as in the first phase of the experiment. The birds in $\mathrm{B}_{1}$ were fed only with the mash feed formulation serving as a control group. The birds in $\mathrm{B}_{2}, \mathrm{~B}_{3}$ and $\mathrm{B}_{4}$ were supplemented with vitamin $\mathrm{C}$, probiotics and AGP, respectively. Standard management and housing conditions were employed for all animals during the experimental procedures. The experiment on animals was approved by the Animal Welfare and Experimentation Ethics Committee, Faculty of Veterinary Science, Bangladesh Agricultural University (Approval No. AWEEC/BAU/2020(30)).

\section{Blood collection for serum sample}

Blood samples were aseptically collected by venipuncture of the brachial vein from five quails in each treatment group. The sampling was performed on two weeks intervals from 2 to 12 weeks of age. Blood serum was obtained according to the methods by Khanam et al. (16) which was used for assessment of antibody titer by using the HI test. The samples were collected from the Japanese quails following standard sample collection procedures from the live birds without any breach of animal welfare policy.

Collection and preparation of $1 \%$ chicken red blood cell (cRBC)

About $5 \mathrm{ml}$ of blood were aseptically collected from a healthy bird using a sterile needle and syringe. A blood collecting vial containing the anticoagulant Alsever's solution (1 part Alsever's to 1 part blood) was used. The $1 \%$ chicken red blood cell (cRBC) was prepared according to the methods of Ambali et al. (17).

\section{Newcastle disease virus antigen preparation}

The antigen was prepared from the NDV strain of the respective vaccines used in this study according to the method described by Khanam et al. (16) and 
Barua et al. (18). The NDV was propagated into chicken embryonated egg according to the method explained by Meher et al. (19). The presence of NDV strain was determined by Slide Hemagglutination (SHA) test. The clumping of cRBC in allantoic fluid of infected chicken embryos within a minute was considered as a positive finding of the virus.

\section{Micro-plate hemagglutination (HA) test}

Micro-plate hemagglutination (HA) test was performed to determine the 4HA units by twofold serial dilution in a U-shaped microtiter plate according to the methods by OIE (7) and Allan and Gough (20).

\section{Hemagglutination inhibition (HI) test}

The serum samples of each bird in its respective group were HI tested (20) by using a 4HA unit in two-fold serial dilutions in a V-shaped microtiter plate to determine the antibody titer against ND. The HI titer was calculated and expressed as a geometric mean titer of $\log _{2}$ values (21) for each group.

\section{Lymphoid organs weight}

At the end of the second phase of the experiment, five birds from each group, at age of 84 days, were sacrificed to collect the lymphoid organs (Bursa of Fabricius, thymus and spleen). After collection, the organs were grossly examined for pathological changes. Fat and tissue debris were removed and organs were weighed to determine the effect of treatment. The lymphoid organ weights were expressed relative to the live body weight (BW) (g/kg).

\section{Lymphoid organs weight (g) Live body weight (g)}

\section{Probiotics, vitamin $C, A G P$ and vaccines}

The birds were supplemented with commercially available probiotics which contained the probiotic bacteria Enterococcus spp., Pediococcus spp., Bifidobacterium spp. and Lactobacillus spp., at least $5 \times 10^{12} \mathrm{CFU} / \mathrm{kg}$. The probiotic stock solution (20 g) was prepared for 1000 birds. It was mixed with drinking water and administered in the morning before feeding for the entire experimental period. Vitamin $\mathrm{C}$ was obtained as a powder which contained $980 \mathrm{mg}$ of L-Ascorbic Acid per gram. It was administered in a dose of $1 \mathrm{~g}$ per 5 to 10 liters of drinking water during the entire experimental period. Commercially available broad-spectrum antibiotic (Ciprofloxacin) was used as AGP. It was administered in a dose of $0.5 \mathrm{~g}$ per $50 \mathrm{~kg}$ of mash feed during the entire experimental period. The vaccine strains used during the experiment were obtained from a local market and were stored and diluted according to Barua et al. (18).

\section{Statistical analysis}

The experimental data were analyzed using Statistical Package for Social Sciences (SPSS), version 25.0. The between-group assessment was performed by One Way Analysis of Variance (ANOVA), whereas the within-group assessment was performed by Repeated Measure Analysis of Variance (ANOVA). The Student-Newman-Keuls test was applied as a post-hock test for the oneway ANOVA, whereas the Bonferroni test was applied for the repeated ANOVA. Furthermore, the correlation of relative organ weight and HI titer at 12 weeks of age was analyzed using Pearson's correlation (r) test. P-values $\leq 0.05$ were considered significant for all tests.

\section{RESULTS}

The level of antibody titer in Japanese quails (Coturnix coturnix japonica) vaccinated by ND vaccine is presented in Table 1 . Four ND vaccines of LaSota, B1, F and VG/GA strains were applied in four experimental groups of Japanese quails. There was no significant difference in the antibody mean titer $\left(\log _{2}\right)$. The highest mean titer value $(6.20 \pm 0.37)$ was obtained in the $A_{4}$ group at 6 and 8 weeks following VG/GA vaccination. The next highest titer was $6.00 \pm 0.71$ in group $A_{3}$ at 8 weeks which gradually declined. The lowest value was obtained in group $\mathrm{A}_{2}(5.00 \pm 0.71)$ at the first and in group $A_{1}(5.00 \pm 0.55)$ at the last week of the experiment. At the same time, repeated measure analysis showed significant differences within the groups in different weeks, especially for groups $A_{1}$ and $A_{3}$, indicating that the level of antibody production fluctuated significantly.

The comparative effect of vitamin $\mathrm{C}$, probiotics and AGP on ND antibody titer of Japanese quails vaccinated with a ND vaccine is shown in Table 2. The $\log _{2}$ antibody means titer was significantly different between the groups $\left(\mathrm{B}_{1}, \mathrm{~B}_{2}\right.$ and $\left.\mathrm{B}_{3}\right)$ at the age of 4 weeks, but insignificant at the age of $2,6,8$, 10 and 12 weeks. The $\mathrm{B}_{2}$ group was not statistically different than the $\mathrm{B}_{3}$ group. At the initial stage 
Table 1. Geometric mean antibody titers $\left(\log _{2}\right)$ against ND virus of Japanese quails (Coturnix coturnix japonica) vaccinated with different ND vaccine measured by $\mathrm{HI}$ test

\begin{tabular}{|c|c|c|c|c|c|c|c|c|}
\hline \multirow[t]{2}{*}{ Group } & \multicolumn{6}{|c|}{$\begin{array}{c}\text { Geometric }\left(\log _{2}\right) \text { mean titer } \pm S E \\
\text { Age of Japanese quails (Weeks) }\end{array}$} & \multirow[t]{2}{*}{ F-value } & \multirow[t]{2}{*}{ LS } \\
\hline & 2 & 4 & 6 & 8 & 10 & 12 & & \\
\hline$A_{1}$ & $5.20^{\mathrm{axy}} \pm 0.58$ & $3.80^{\text {ay }} \pm 0.49$ & $5.40^{\mathrm{axy}} \pm 0.51$ & $5.80^{\mathrm{ax}} \pm 0.37$ & $5.60^{\mathrm{axy}} \pm 0.51$ & $5.00^{\mathrm{axy}} \pm 0.55$ & 10.857 & $* *$ \\
\hline $\mathbf{A}_{2}$ & $5.00^{\mathrm{ax}} \pm 0.71$ & $4.20^{\mathrm{ax}} \pm 0.58$ & $5.60^{\mathrm{ax}} \pm 0.51$ & $5.60^{\mathrm{ax}} \pm 0.51$ & $5.60^{\mathrm{ax}} \pm 0.68$ & $5.20^{\mathrm{ax}} \pm 0.58$ & 6.423 & * \\
\hline $\mathbf{A}_{3}$ & $5.40^{\mathrm{axy}} \pm 0.60$ & $4.00^{\mathrm{ay}} \pm 0.55$ & $5.80^{\mathrm{ax}} \pm 0.37$ & $6.00^{\mathrm{ax}} \pm 0.71$ & $5.60^{\mathrm{ax}} \pm 0.68$ & $5.40^{\mathrm{axy}} \pm 0.51$ & 9.544 & $* *$ \\
\hline $\mathbf{A}_{4}$ & $5.40^{\mathrm{axy}} \pm 0.51$ & $4.40^{\mathrm{ay}} \pm 0.51$ & $6.20^{\mathrm{axy}} \pm 0.37$ & $6.20^{\mathrm{ax}} \pm 0.58$ & $5.80^{\mathrm{axy}} \pm 0.66$ & $5.40^{\mathrm{axy}} \pm 0.51$ & 7.031 & $*$ \\
\hline F-value & 0.100 & 0.234 & 0.583 & 0.215 & 0.025 & 0.126 & & \\
\hline $\mathbf{L S}$ & NS & NS & NS & NS & NS & NS & & \\
\hline
\end{tabular}

abc: Column values with same letters do not differ significantly; ${ }^{\text {xyz }}$ : Row values with similar letters do not differ significantly; LS $=$ Level of significance; NS=Non-significant; *Significant at $5 \%(\mathrm{p}<0.05) ;{ }^{*} *$ Significant at $1 \%(\mathrm{p}<0.01) . \mathrm{A}_{1}=\mathrm{Vaccinated}$ by LaSota strain; $A_{2}=$ Vaccinated by $B 1$ strain; $A_{3}=$ Vaccinated by $F$ strain; $A_{4}=$ Vaccinated by VG/GA strain

Table 2. Geometric mean antibody titers ( $\left.\log _{2}\right)$ of ND vaccinated Japanese quails (Coturnix coturnix japonica) supplemented with vitamin $\mathrm{C}$, probiotics and AGP

\begin{tabular}{ccccccc}
\hline \multirow{2}{*}{ Group } & \multicolumn{7}{c}{ Geometric $\begin{array}{c}\left(\mathbf{L o g}_{2}\right) \text { mean titer } \pm \mathbf{S E} \\
\text { Weeks }\end{array}$} \\
\cline { 2 - 7 } & $\mathbf{2}$ & $\mathbf{4}$ & $\mathbf{6}$ & $\mathbf{8}$ & $\mathbf{1 0}$ & $\mathbf{1 2}$ \\
\hline $\mathbf{B}_{1}$ & $5.40^{\mathrm{a}} \pm 0.60$ & $3.80^{\mathrm{b}} \pm 0.37$ & $5.80^{\mathrm{a}} \pm 0.37$ & $5.60^{\mathrm{a}} \pm 0.51$ & $5.60^{\mathrm{a}} \pm 0.51$ & $5.60^{\mathrm{a}} \pm 0.51$ \\
$\mathbf{B}_{2}$ & $6.40^{\mathrm{a}} \pm 0.51$ & $6.00^{\mathrm{a}} \pm 0.55$ & $6.80^{\mathrm{a}} \pm 0.37$ & $7.40^{\mathrm{a}} \pm 0.60$ & $7.40^{\mathrm{a}} \pm 0.60$ & $7.00^{\mathrm{a}} \pm 0.55$ \\
$\mathbf{B}_{3}$ & $6.40^{\mathrm{a}} \pm 0.51$ & $6.20^{\mathrm{a}} \pm 0.58$ & $7.00^{\mathrm{a}} \pm 0.45$ & $7.20^{\mathrm{a}} \pm 0.58$ & $7.20^{\mathrm{a}} \pm 0.58$ & $6.80^{\mathrm{a}} \pm 0.37$ \\
$\mathbf{B}_{4}$ & $5.60^{\mathrm{a}} \pm 0.51$ & $4.80^{\mathrm{ab} \pm 0.37}$ & $6.20^{\mathrm{a}} \pm 0.58$ & $6.00^{\mathrm{a}} \pm 0.55$ & $5.80^{\mathrm{a}} \pm 0.37$ & $5.20^{\mathrm{a}} \pm 0.58$ \\
F value & 0.971 & 5.449 & 1.480 & 2.487 & 3.152 & 3.013 \\
LS & $\mathrm{NS}$ & $*$ & $\mathrm{NS}$ & $\mathrm{NS}$ & $\mathrm{NS}$ & $\mathrm{NS}$ \\
\hline
\end{tabular}

abc: Column values with same letters do not differ significantly; LS=Level of significance; NS=Non-significant; *Significant at 5\% $(\mathrm{p}<0.05)$; **Significant at $1 \%(\mathrm{p}<0.01) . \mathrm{B}_{1}=$ Mesh-feed with no supplements; $\mathrm{B}_{2}=$ Supplemented by vitamin $\mathrm{C}$; $\mathrm{B}_{3}=$ Supplemented by probiotics; $\mathrm{B}_{4}=$ Supplemented by Antibiotics Growth Promoter (AGP)

after vaccination, the lowest antibody titer was $5.40 \pm 0.60$ in the $B_{1}$ group and the highest was $6.4 \pm 0.51$ in $B_{2}$ and $B_{3} . B_{4}$ had the lowest antibody titer $(5.20 \pm 0.58)$ at 12 weeks, whereas group $\mathrm{B}_{2}$ had the highest $(7.00 \pm 0.55)$ at the same time. An increased geometric mean titer was observed in the $\mathrm{B}_{2}$ group at 8 to 10 weeks of age $(7.40 \pm 0.60)$ which was the highest recorded value. The $\mathrm{B}_{3}$ group had the second highest-value (7.20 \pm 0.58$)$.

The lymphoid organs' (Bursa of Fabricius, thymus and spleen) relative weight $(\mathrm{gm} / \mathrm{kg})$ were recorded immediately after the slaughter at the end (12 weeks) of the second phase of the experiment (Table 3). The relative weight of the spleen, thymus and bursa were significantly $(\mathrm{p}<0.01)$ different between the four groups $\left(\mathrm{B}_{1}, \mathrm{~B}_{2}, \mathrm{~B}_{3}\right.$ and $\left.\mathrm{B}_{4}\right)$. The highest relative weight $(\mathrm{gm} / \mathrm{kg})$ of spleen was found in $\mathrm{B}_{3}(1.947 \pm 0.109)$ which was significantly different than $\mathrm{B}_{1}(1.173 \pm 0.085)$ and $\mathrm{B}_{4}(1.278 \pm 0.047)$, but insignificantly different than $\mathrm{B}_{2}(1.791 \pm 0.157)$.
Similarly, a significantly higher relative weight of the thymus was measured in group $\mathrm{B}_{3}(5.951 \pm 0.312)$. A significantly lower relative weight was measured in group $\mathrm{B}_{1}(4.214 \pm 0.210)$ compared to $\mathrm{B}_{2}(5.759 \pm 0.334)$ and $B_{3}$ samples $(5.951 \pm 0.312)$, but it was insignificantly different compared to $\mathrm{B}_{4}(4.459 \pm 0.326)$. The relative weight of bursa in groups $B_{2}(2.474 \pm 0.150)$ and $B_{3}$ (2.624 \pm 0.083$)$ were significantly different compared to groups $\mathrm{B}_{4}(1.822 \pm 0.104)$ and $\mathrm{B}_{1}(1.686 \pm 0.141)$. The lowest measured relative weight value of bursa was in the $\mathrm{B}_{1}$ group.

Pearson's correlation (r) was calculated to determine the correlation between the lymphoid organs' relative weight and mean antibody titer $\left(\log _{2}\right)$ at the age of 12 weeks (Table 4). Despite the high correlation coefficients (r) between lymphoid organs relative weight and mean antibody titer $\left(\log _{2}\right)$, only those observed between thymus and bursa in the $\mathrm{B}_{1}$ group $(\mathrm{r}=0.908$ and 0.885 , respectively) were statistically significant. 
Table 3. Effect of vitamin C, probiotics and AGP on lymphoid organs relative weight $(\mathrm{g} / \mathrm{kg})$ of Japanese quails (Coturnix coturnix japonica) vaccinated against ND virus at 12 week of age

\begin{tabular}{lccc}
\hline \multirow{2}{*}{ Group } & \multicolumn{3}{c}{ Mean $\pm \mathbf{S E}$} \\
\cline { 2 - 4 } & Spleen & Thymus & Bursa \\
\hline $\mathbf{B}_{1}$ & $1.173^{\mathrm{b}} \pm 0.085$ & $4.214^{\mathrm{b}} \pm 0.210$ & $1.686^{\mathrm{b}} \pm 0.141$ \\
$\mathbf{B}_{2}$ & $1.791^{\mathrm{a}} \pm 0.157$ & $5.759^{\mathrm{a}} \pm 0.334$ & $2.474^{\mathrm{a}} \pm 0.150$ \\
$\mathbf{B}_{3}$ & $1.947^{\mathrm{a}} \pm 0.109$ & $5.951^{\mathrm{a}} \pm 0.312$ & $2.624^{\mathrm{a}} \pm 0.083$ \\
$\mathbf{B}_{4}$ & $1.278^{\mathrm{b}} \pm 0.047$ & $4.459^{\mathrm{b}} \pm 0.326$ & $1.822^{\mathrm{b}} \pm 0.104$ \\
F value & 12.515 & 8.743 & 14.501 \\
LS & $* *$ & $* *$ & $* *$ \\
\hline
\end{tabular}

abc: Column values with same letters do not differ significantly; LS=Level of significance; NS=non-significant; **Significant at $1 \%(\mathrm{p}<0.01) . \mathrm{B}_{1}=$ Mesh-feed with no supplements; $\mathrm{B}_{2}=$ Supplemented by vitamin $\mathrm{C}$; $\mathrm{B}_{3}=$ Supplemented by probiotics; $\mathrm{B}_{4}=$ Supplemented by Antibiotics Growth Promoter (AGP)

Table 4. Correlation between lymphoid organ weight and antibody titer against ND at 12 weeks of age in Japanese quails (Coturnix coturnix japonica) supplemented with vitamin C, probiotics and AGP

\begin{tabular}{ccccc}
\hline \multirow{2}{*}{$\begin{array}{c}\text { Lymphoid organ } \\
\text { weight }(\mathbf{g m})\end{array}$} & \multicolumn{4}{c}{ Pearson's correlation $(\mathbf{r})$} \\
\cline { 2 - 4 } & $\mathbf{B}_{1}$ & $\mathbf{B}_{2}$ & $\mathbf{B}_{\mathbf{3}}$ & $\mathbf{B}_{4}$ \\
\cline { 2 - 4 } Spleen & 0.873 & 0.833 & 0.493 & 0.339 \\
Thymus & $0.885^{*}$ & 0.274 & 0.381 & -0.514 \\
Bursa & $0.908^{*}$ & 0.249 & 0.192 & -0.100 \\
\hline
\end{tabular}

*Correlation is significant at $5 \%(\mathrm{p}<0.05)\left(2\right.$-tailed); ${ }^{* *}$ Correlation is significant at $1 \%(\mathrm{p}<0.01)$ level (2-tailed); $\mathrm{B}=$ Mesh-feed with no supplements; $\mathrm{B}_{2}=$ Supplemented by vitamin $\mathrm{C} ; \mathrm{B}_{3}=$ Supplemented by probiotics; $\mathrm{B}_{4}=$ Supplemented by Antibiotics Growth Promoter (AGP)

\section{DISCUSSION}

A protective antibody titer against ND is essential for optimal protection and productive performance in quails. Despite that all the ND vaccine strains (LaSota, B1, VG/GA or F) are capable to induce optimum antibody levels in Japanese quails, the VG/GA strain was demonstrated to induce the highest antibody level in this study. These findings are in accordance with Barua et al. (18) who showed that VG/GA strain produced better immunity than the F, B1 and LaSota strains in broilers. Additionally, Mahmud et al. (22) found a higher performance of commercial vaccine named Avinew (VG/GA strain) in comparison with BCRDV ( $F$ strain) in broilers which support our findings. The higher performance of the VG/GA strain vaccine is supposed to be achieved by obtaining the virus with 'Cloning' (23). However, Ibrahim et al. (24) did not find a significant difference when comparing F, B1 and LaSota strains of ND vaccines. This report was in agreement with our findings where similar levels of mean antibody $\mathrm{HI}$ titers were produced by LaSota, B1, F and VG/GA strain. The antibody titer peak in this study was achieved at 25 days after the second dose of the vaccine (at 30 days) and lasted for 2 weeks. The findings of Rahman et al. (25) suggested that the HI antibody titers attain the peak between 2 and 3 weeks after the broiler vaccination. Perhaps these dissimilar findings could be due to the variation in species and the sampling schedule. The findings of Abdel et al. (26) indicated that the HI antibody titer culminated at 28 days post-vaccination in Japanese quails which is similar to our findings. In the vaccination trial with the supplementation of vitamin $\mathrm{C}\left(\mathrm{B}_{2}\right)$, probiotics $\left(\mathrm{B}_{3}\right)$ and AGP $\left(\mathrm{B}_{4}\right)$ it was demonstrated that the immune response was significantly higher compared to the control group at week 4. Though the mean antibody titer at 2, 6, 8, 10 and 12 weeks of age did not differ significantly among the groups $\left(\mathrm{B}_{1}, \mathrm{~B}_{2}, \mathrm{~B}_{3}\right.$ and $\left.\mathrm{B}_{4}\right)$, it was evident that a higher mean antibody titer was achieved in $\mathrm{B}_{2}$ and $\mathrm{B}_{3}$ groups. Therefore, it is indicative that vitamin $\mathrm{C}$ and probiotics could achieve a beneficial effect on the immune response during vaccination in Japanese quails. This is in agreement with other research reports that supplemented vitamin C (27) 
and probiotics (28), thus achieving considerably higher levels of mean antibody titers compared to other supplemented diets. The beneficial effect of vitamin $\mathrm{C}$ could be due to its antioxidant properties, protecting immature lymphocytes from free radicals thus enhancing immune response (29). The beneficial effects of the probiotic-supplemented group could be ascribed to its immunomodulatory role on the antibodies (30). Similarly, Maassen et al. (31) stated that probiotics of Lactobacillus strains significantly enhanced the $\operatorname{IgG}$ response. Cheng et al. (32) reported that probiotics enhanced cell-mediated immune responses in broilers by modulating macrophage activity. However, the exact immunomodulatory mechanisms of probiotics have not yet been fully explained. It is supposed that they may act by stimulating different immune-cells $(33,34)$.

The effect of dietary supplementation on lymphoid organs relative weights $(\mathrm{g} / \mathrm{kg})$ (spleen, thymus and bursa) was found to be significant. The probiotics group $\left(\mathrm{B}_{3}\right)$ had higher lymphoid organ weights. Willis et al. (35) reported an increase in the relative weight of spleen in broilers fed with probiotics which is in agreement with the current study findings. Similarly, Khan et al. (36) reported higher weights of the thymus as a result of probiotic feed supplementation due to its effects on the immune system. Kumar et al. (37) reported higher weight of bursa in treatment groups supplemented with probiotics compared to control and AGP supplemented groups. In the current study, the lymphoid organs had higher weights in the vitamin C supplemented group $\left(\mathrm{B}_{2}\right)$ compared to the control $\left(\mathrm{B}_{1}\right)$ and AGP $\left(\mathrm{B}_{4}\right)$ supplemented groups. This was in agreement with Bhatti et al. (27) who reported higher weights of bursa, spleen and thymus in group treated with vitamin $\mathrm{C}+\mathrm{E}$, but no comparison was made with probiotics supplemented groups. This study found an insignificantly high correlation level between feed-supplementation of vitamin $\mathrm{C}\left(\mathrm{B}_{2}\right)$ and probiotics $\left(\mathrm{B}_{3}\right)$ with antibody titer in Japanese quails which could be explained due to the small sample size.

\section{CONCLUSION}

The virus strains of ND vaccines used in the current study had a small variation in the efficacy of antibody production in quails. The VG/GA vaccine strain-induced insignificantly higher antibody titer compared to B1, LaSota and $\mathrm{F}$. The vaccine was more effective when used with feed-supplementation of vitamin C. Similarly, supplementation of probiotics was more effective than AGP which resulted in higher antibody production and significantly higher lymphoid organ weight gain in Japanese quails. Therefore, the VG/GA strain of ND vaccine used with feed-supplementation of vitamin $\mathrm{C}$ or probiotics can boost the antibody titer against ND in Japanese quails. Further studies should assess the efficacy of other ND vaccine strains in different environmental and climatic conditions in poultry as well as the immune-modulatory effects of feedsupplementation of vitamin $\mathrm{C}$ and probiotics.

\section{CONFLICT OF INTEREST}

The authors declared that they have no potential conflict of interest with respect to the authorship and/or publication of this article.

\section{ACKNOWLEDGEMENTS}

This research was supported by the Department of Anatomy and Histology, Bangladesh Agricultural University as well as the Department of Microbiology and Public Health, Bangabandhu Sheikh Mujibur Rahman Agricultural University.

\section{AUTHORS' CONTRIBUTION}

MA planned and designed the experiment. NJ involved in rearing the experimental birds and sample collection. MMM statistically analyzed the data. MMM and MA carried out the experimental work, wrote and reviewed the manuscript. All authors read and approved the final manuscript.

\section{REFERENCES}

1. Onyewuchi, U.U., Offor, I.R., Okoli, C.F. (2013). Profitability of quail bird and egg production in IMO state, Nigeria. J Agric Food Environ. 9(1): 40-44.

2. Susta, L., Segovia, D., Olivier, T.L., Dimitrov, K.M., Shittu, I., Marcano, V., Miller, P.J. (2018). Newcastle disease virus infection in quail. Vet Pathol. 55(5): 682-692.

https://doi.org/10.1177/0300985818767996 PMid:29661124

3. Islam, M.A., Ito, T., Takakuwa, H., Takada, A., Itakura, C., Kida, H. (1994). Acquisition of pathogenicity of a Newcastle disease virus isolated from a Japanese quail by intracerebral passage in chickens. Jpn J Vet Res. 42(3-4): 147-156. 
4. Merino, R., Villegas, H., Quintana, J.A., Calderon, N. (2009). Characterization of Newcastle disease viruses isolated from chicken, gamefowl, pigeon and quail in Mexico. Vet Res Commun. 33(8): 1023-1030. https://doi.org/10.1007/s11259-009-9321-5 PMid:19784791

5. De Leeuw, O., Peeters, B. (1999). Complete nucleotide sequence of Newcastle disease virus: Evidence for the existence of a new genus within the subfamily Paramyxovirinae. J Gen Virol. 80(1): 131-136.

https://doi.org/10.1099/0022-1317-80-1-131

PMid:9934695

6. Alexander, D.J. (2000). Newcastle disease and other avian paramyxoviruses. Rev Sci Tech. 19(2): 443-462.

https://doi.org/10.20506/rst.19.2.1231

PMid:10935273

7. OIE (2019). Manual of diagnostic tests and vaccines for terrestrial animals. Newcastle disease (infection with Newcastle disease virus) [Internet]. Section 3.3. Chapter 3.3.14.

https://www.oie.int/fileadmin/Home/eng/Health_ standards/tahm/3.03.14_NEWCASTLE_DIS.pdf

8. Puthpongsiriporn, U., Scheideler, S.E., Sell, J.L., Beck, M.M. (2001). Effects of vitamin E and C supplementation on performance, in vitro lymphocyte proliferation, and antioxidant status of laying hens during heat stress. Poult Sci. 80(8): 1190-1200.

https://doi.org/10.1093/ps/80.8.1190

PMid:11495472

9. Wu, C.C., Dorairajan, T., Lin, T.L. (2000). Effect of ascorbic acid supplementation on the immune response of chickens vaccinated and challenged with infectious bursal disease virus. Vet Immunol Immunopathol. 74(1-2): 145-152.

https://doi.org/10.1016/S0165-2427(00)00161-6

10. Aengwanich, W., Sridama, P., Phasuk, Y. Vongpralab, T., Pakdee, P., Katawatin, S., Simaraks, S. (2003). Effects of ascorbic acid on cell mediated, humoral immune response and pathophysiology of white blood cells in broilers under heat stress. Songklanakarin J Sci Technol. 23(3): 2297-305.

11. Haghighi, H.R., Gong, J., Gyles, C.L., Hayes, M.A., Zhou, H., Sanei, B., Chambers J.R., Sharif, S. (2006). Probiotics stimulate production of natural antibodies in chickens. Clin Vaccine Immunol. 13(9): 975-980.

https://doi.org/10.1128/CVI.00161-06

PMid:16960107 PMCid:PMC1563569
12. El-Shall, N.A., Awad, A.M., El-Hack, M.E.A., Naiel, M.A.E., Othman, S.I., Allam, A.A., Sedeik, M.E. (2019). The simultaneous administration of a probiotic or prebiotic with live salmonella vaccine improves growth performance and reduces fecal shedding of the bacterium in Salmonella-challenged broilers. Animals (Basel). 10(1): 70.

https://doi.org/10.3390/ani10010070

PMid:31906020 PMCid:PMC7023486

13. Isolauri, E., Sütas, Y., Kankaanpää, P., Arvilommi, H., Salminen, S. (2001). Probiotics: Effects on immunity. Am J Clin Nutr. 73(2): 444s-450s.

https://doi.org/10.1093/ajen/73.2.444s

PMid:11157355

14. Lokapirnasari, W.P., Al Arif, A., Soeharsono, S., Fathinah, A., Najwan, R., Wardhani, H.C.P., et al. (2019). Improves in external and internal egg quality of Japanese quail (Coturnix coturnix japonica) by giving lactic acid bacteria as alternative antibiotic growth promoter. Iran J Microbiol. 11(5): 406-411.

15. Razee, A., Mahbub, A.S.M., Miah, M.Y., Hasnath, M.R., Hasan, M.K., Uddin, M.N., et al. (2016). Performance of Japanese quails ( Coturnix coturnix japonica) on floor and cage rearing system in Sylhet, Bangladesh: Comparative Study. Iran J Appl Anim Sci. 6(4): 931-936.

16. Khanam, J., Rahman, M.M., Fakhruzzaman, M., Rumi, N.A. (2018). Determination of efficacy of different Newcastle disease vaccine used in broiler chickens. Asian Australas J Biosci Biotechnol. 3(1): 52-58.

17. Ambali, H.M., Nwoha, R.I.O., Abdu, P.A. (2017). Evaluation of antibody response to Newcastle disease vaccination in chickens in some commercial farms-Ii two local government areas in Lagos State, Nigeria. J Vet Med Surg. 1(2:10): 1-6. https://doi.org/10.9734/AJEA/2016/27456

18. Barua, A.R., Amin, M.M., Islam, S., Chowdhury, S., Khan, M.S.I., Asgar, M.A. (2008). Evaluation of antibody production against Newcastle disease virus after immunization with different vaccines in Fayoumi chicks. Bangladesh J Microbiol. 25(1):31-35. https://doi.org/10.3329/bjm.v25i1.4852

19. Meher, M.M., Rahman, M.M., Akter, M.R., Rahaman, M.S., Rahman, M.K. (2017). Detection of avian infectious bronchitis virus and its specific antibody in different ages layer birds in Dinajpur district of Bangladesh. Int J Res Appl Sci Eng Technol. 5(11): 2502-2507.

https://doi.org/10.22214/ijraset.2017.11350 
20. Allan, W.H., Gough, R.H. (1974). A standard hemagglutination inhibition test for Newcastle disease. (1). A comparison of macro and micromethods. Vet Rec. 95(6): 120-123.

https://doi.org/10.1136/vr.95.6.120

PMid:4446306

21. Brugh, M.G. (1978). A simple method for recording and analyzing serological data. Avian Dis. 22(2): 362-365.

https://doi.org/10.2307/1589552

PMid:678239

22. Mahmud, M.S., Hossain, M.T., Monoura, P., Amin, M.M. (2007). Comparative efficacy of avinew (VG/GA strain) and BCRDV (F strain) vaccines against Newcastle disease in broiler chickens. Bangladesh J Vet Med. 5(1-2): 19-23. https://doi.org/10.3329/bjvm.v5i1.1304

23. Borland, L.J., Allan, W.H. (1980). Laboratory tests for comparing live lentogenic newcastle disease vaccines. Avian Pathol. 9(1): 45-59.

https://doi.org/10.1080/03079458008418385 PMid:18770239

24. Ibrahim, A.L., Lai, M.C., Aini, I. (1983). Spray vaccination with an improved $F$ Newcastle disease vaccine. A comparison of efficacy with the B1 and La Sota vaccines. Br Vet J. 139(3): 213-219. https://doi.org/10.1016/S0007-1935(17)30486-4

25. Rahman, M.B., Rahman, M.M., Rahman, M., Kabir, S.M.L., Nazir, K.H.M.N.H., Amin, M.M. (2004). Efficacy of V4HR newcastle disease (V4HR-ND) vaccine in broiler birds in Bangladesh. Int J Poult Sci. 3(5): 365-368.

https://doi.org/10.3923/ijps.2004.365.368

26. Abdel Rhman, S.S., Al Jassem, A.H., Hussein, G.M., Al-Blowi, M.H. (2013). Comparison between haemagglutination inhibition test and enzyme linked immune sorbent assay in evaluation of Newcastle disease antibodies in Japanese quails. J World's Poult Res. 3(3): 83-88.

27. Bhatti,N.,Hussain,Z., Mukhtar, M., Ali,A.,Imran,M., Rafique, A., Manzoor, S., Rehman, S. (2016). Effects of vitamins $\mathrm{E}$ and $\mathrm{C}$ supplementation on the immune response of broiler chicks. J Antivir Antiretrovir. 8(4): 151-154.

28. Talebi, A., Amirzadeh, B., Mokhtari, B., Gahri, H. (2008). Effects of a multi-strain probiotic (PrimaLac) on performance and antibody responses to Newcastle disease virus and infectious bursal disease virus vaccination in broiler chickens. Avian Pathol. 37(5): 509-512.

https://doi.org/10.1080/03079450802356995

PMid:18798026
29. Elagib, H.A.A., Omer, H.M. (2012). Effect of dietary ascorbic acid on performance and immune response of heat stressed broiler chicks. Pakistan J Nutr. 11(3): 216-220.

https://doi.org/10.3923/pjn.2012.216.220

30. Huang, Z., Elankumaran, S., Yunus, A.S., Samal, S.K. (2004). A recombinant Newcastle disease virus (NDV) expressing VP2 protein of infectious bursal disease virus (IBDV) protects against NDV and IBDV. J Virol. 78(18): 10054-10063.

https://doi.org/10.1128/JVI.78.18.10054-10063.2004 PMid:15331738 PMCid:PMC514986

31. Maassen, C.B.M., Van Holten-Neelen, C., Balk, F., Den Bak-Glashouwer, M.J., Leer, R.J., Laman, J.D., Boersma, W.J., Claassen, E. (2000). Straindependent induction of cytokine profiles in the gut by orally administered Lactobacillus strains. Vaccine. 18(23): 2613-2623. https://doi.org/10.1016/S0264-410X(99)00378-3

32. Cheng, Y.H., Lee, D.N., Wen, C.M., Weng, C.F. (2004). Effects of $\beta$-glucan supplementation on lymphocyte proliferation, macrophage chemotaxis and specific immune responses in broilers. AsianAustralas J Anim Sci. 17(8): 1145-1149.

https://doi.org/10.5713/ajas.2004.1145

33. Christensen, H.R., Frøkiær, H., Pestka, J.J. (2002). Lactobacilli differentially modulate expression of cytokines and maturation surface markers in murine dendritic cells. J Immunol. 168(1): 171-178. https://doi.org/10.4049/jimmunol.168.1.171 PMid:11751960

34. Bai, A.P., Ouyang, Q., Zhang, W., Wang, C.H., Li, S.F. (2004). Probiotics inhibit TNF- $\alpha$-induced interleukin-8 secretion of HT29 cells. World J Gastroenterol. 10(3): 455-457. https://doi.org/10.3748/wjg.v10.i3.455 PMid:14760780 PMCid:PMC4724907

35. Willis, W.L., Isikhuemhen, O.S., Ibrahim, S.A. (2007). Performance assessment of broiler chickens given mushroom extract alone or in combination with probiotics. Poult Sci. 86(9): 1856-1860. https://doi.org/10.1093/ps/86.9.1856 PMid:17704371 
36. Khan, S.H., Yousaf, B., Mian, A.A., Rehman, A., Farooq, M.S. (2011). Assessing the effect of administering different probiotics in drinking water supplement on broiler performance, blood biochemistry and immune response. J Appl Anim Res. 39(4): 418-428.

https://doi.org/10.1080/09712119.2011.623783
37. Kumar, M.V., Patil, V.M., Kiran, M., Tendulkar, S.M. (2018). Effect of dietary supplementation of probiotics (Addon Poultry Max) on biochemical and immune parameters in commercial broiler chicken. Int J Curr Microbiol Appl Sci. 7(10): 1537-1542. https://doi.org/10.20546/ijcmas.2018.710.171 